Nig. J. Anim. Prod. 2021, 48(3): 193- 203. doi.org/10.51791/njap.v48i3.2950 (C) Nigerian Society for Animal Production

\title{
An in-vitro evaluation of the potentials of turmeric as phytogenic feed additive for
} rumen modification

Aderinboye, R. Y. and Olanipekun, A. O.

Department of Animal Nutrition, College of Animal Science and Livestock Production, Federal University of Agriculture, Abeokuta

Corresponding author: aderinboyery@funaab.edu.ng; +2349033795787

\section{Abstract}

The potential risk to animal and human health in the use of antibiotic feed additives for modifying rumen fermentation has necessitated the search for natural alternatives which are generally regarded as safe. The aim of this study was to evaluate the potentials of turmeric powder in rumen manipulation using the in vitro method. Substrate of Panicum maximum and concentrate in ratio 6: 4 with turmeric inclusion at four levels of 0, 5, 10 and $15 \mathrm{mg} / \mathrm{g} d r y$ matter (DM) were used for this study. The experiment was arranged in a completely randomized design. Approximately $200 \mathrm{mg}$ of substrate in each treatment was weighed separately into $100 \mathrm{~mL}$ glass syringes into which $30 \mathrm{~mL}$ of rumen fluid and buffer solution $(1: 2 \mathrm{v} / \mathrm{v})$ were added. The quantities of total gas, methane, ammonia, total volatile fatty acids production and substrate degraded were determined 48- $h$ post incubation. Rumen bacteria, protozoa, fungi population were determined and microbial biomass was estimated. Some phytochemical constituents of turmeric were also determined using standard methods. Turmeric had a higher percentage of curcumin relative to other phytochemical contents determined. Turmeric effectively and consistently $(p<0.05)$ reduced gas production at levels above $5 \mathrm{mg} / \mathrm{g}$ of substrate inclusion throughout the 48-h incubation period. Similarly, turmeric reduced $(p<0.05)$ methane, carbon-dioxide, ammonia and total volatile fatty acids production, and substrate degradation at 10 - $15 \mathrm{mg} / \mathrm{g}$ inclusion. Rumen bacteria and protozoa reduced when turmeric was included at $10-15 \mathrm{mg} / \mathrm{g}$ while fungi reduction was observed at $15 \mathrm{mg} / \mathrm{g}$ of inclusion. Reduction in microbial biomass was observed at $15 \mathrm{mg} / \mathrm{g}$ of turmeric inclusion. It can be concluded from this study that turmeric inclusion above $5 \mathrm{mg} / \mathrm{g}$ DM of substrate, can modify the rumen by causing a reduction in fermentation end-products. The reduction of ammonia production at $15 \mathrm{mg} / \mathrm{g}$ which significantly reduced microbial biomass has implication for lowering microbial protein synthesis.

Keywords: Rumen manipulation, turmeric, incubation, microbial protein

\section{Une évaluation in vitro des potentiels du curcuma comme additif phytogénique pour la modification du rumen}

\section{Résumé}

Le risque potentiel pour la santé animale et humaine dans l'utilisation d'additifs alimentaires antibiotiques pour modifier la fermentation du rumen a nécessité la recherche d'alternatives naturelles qui sont généralement considérées comme sûres. Le but de cette étude était d'évaluer les potentiels de la poudre de curcuma dans la manipulation du rumen en utilisant la méthode in vitro. Substrat de Panicum maximum et concentré dans le rapport 6: 4 avec l'inclusion de curcuma à quatre niveaux de 0, 5, 10 et $15 \mathrm{mg} / \mathrm{g}$ de matière sèche (DM) ont été utilisés pour cette étude. L'expérience a été organisée dans une conception complètement randomisée. Environ $200 \mathrm{mg}$ de substrat dans chaque traitement ont été pesés séparément dans des seringues en verre de $100 \mathrm{~mL}$ dans lesquelles $30 \mathrm{~mL}$ de liquide rumen et de solution 
tampon $(1: 2 \mathrm{v} / \mathrm{v})$ ont été ajoutés. Les quantités totales de gaz, de méthane, d'ammoniac, de production totale d'acides gras volatils et de substrat dégradé ont été déterminées 48 h après incubation. La bactérie Rumen, le protozoaire, la population de champignons ont été déterminés et la biomasse microbienne a été estimée. Certains constituants phytochimiques du curcuma ont également été déterminés à l'aide de méthodes standard. Le curcuma avait un pourcentage plus élevé de curcumine par rapport à d'autres contenus phytochimiques déterminés. Le curcuma a réduit efficacement et systématiquement $(p<0,05)$ la production de gaz à des niveaux supérieurs à $5 \mathrm{mg} / \mathrm{g}$ d'inclusion du substrat tout au long de la période d'incubation de $48 \mathrm{~h}$. De même, le curcuma a réduit $(p<0,05)$ le méthane, le dioxyde de carbone, l'ammoniac et la production totale d'acides gras volatils, et la dégradation du substrat à 10 à $15 \mathrm{mg} / \mathrm{g}$ d'inclusion. Les bactéries rumen et le protozoaire ont diminué lorsque le curcuma a été inclus à $10-15 \mathrm{mg} / \mathrm{g}$ tandis que la réduction des champignons a été observée à $15 \mathrm{mg} / \mathrm{g}$ d'inclusion. La réduction de la biomasse microbienne a été observée à 15 $\mathrm{mg} / \mathrm{g}$ d'inclusion de curcuma. On peut conclure de cette étude que l'inclusion de curcuma audessus de $5 \mathrm{mg} / \mathrm{g}$ de DM de substrat, peut modifier le rumen en causant une réduction des produits finaux de fermentation. La réduction de la production d'ammoniac à $15 \mathrm{mg} / \mathrm{g}$, ce qui a considérablement réduit la biomasse microbienne, a des répercussions sur l'abaissement de la synthèse des protéines microbiennes.

Mots-clés: Manipulation rumen, curcuma, incubation, protéine microbienne

\section{Introduction}

Modifying the rumen fermentation process to reduce feed nutrient losses is of great significance both to the ruminant animal and to the environment (Tadesse, 2014; Subepang et al., 2019). The process of feed fermentation by rumen microbes generates end-products which include volatile fatty acids, ammonia, hydrogen, carbon-dioxide and methane. The volatile fatty acids are the major source of energy to the ruminant while the ammonia produced from the deamination of dietary nitrogen, are utilized for microbial protein synthesis necessary for microbial proliferation. However, dietary proteins and energy losses occur in the rumen in form of ammonia and methane, respectively (Ulfina et al., 2019). The deamination of dietary nitrogen in the rumen leading to excessive production of ammonia which eventually are absorbed via the rumen wall is a wasteful use of dietary nitrogen, as it results to inefficient nitrogen retention (Eschenlauer et al., 2002). Methanogenic archaea present in the rumen, utilize hydrogen and carbondioxide produced during microbial feed fermentation in the rumen to form methane (Chuntrakort et al., 2014; Patra et al., 2017). A loss of $2-15 \%$ of gross energy intake associated with enteric methane emission has been reported (Tadesse, 2014; Wanapat et al., 2015). Therefore, in addition to excessive ammonia production, emission of enteric methane is another significant waste of dietary nutrients, which makes the fermentation process not completely effective (Castillo-Gonzalez et al., 2014). Shifting rumen fermentation away from methane and excessive ammonia production, is a beneficial step towards achieving efficient rumen fermentation. Several rumen modification strategies have been employed in this regard, one of which includes the use of phytogenic plant extracts and their secondary metabolites (Tadesse, 2014). Several in vitro and in vivo studies on different plants, plant extract or essential oils have been carried out in a bid to examine the influence of plant secondary metabolites in ruminants (Hassan et al., 2020). It is well established that plant secondary metabolites have antibacterial 


\section{Aderinboye and Olanipekun}

properties (Compeer and Ynalvez, 2005; Reddy et al., 2020) which is the basis for exploring them as rumen modifying agents. Turmeric (Curcuma longa) is the rhizome of an herbaceous perennial plant which belongs to the family Zingiberaceae (Thangavel and Dhivya, 2019). It has long been used for medicinal purposes and in various nutritional applications (Chatzinasiou et al., 2019). Turmeric is rich in curcuminoids, a polyphenolic compound which contains $70-77 \%$ curcumin, $18-20 \%$ demethoxycurcumin and 7-10\% bisdemethoxycurcumin (Pradeep et al., 2016). These active constituents of turmeric are known to exhibit a wide range of biological activities which includes antibacterial and antifungal activities (Kebede et al., 2021). In a bid to search for natural and readily available alternatives to antibiotic-based rumen modifiers, this study aimed at exploring the potentials of turmeric as a rumen modifying feed additive with a view of determining its level of inclusion in the diet for achieving rumen fermentation changes.

\section{Materials and methods Experimental location}

The experiment was carried out at the Animal Nutrition Laboratory of the College of Animal Science and Livestock production, Federal University of Agriculture, Abeokuta, Ogun State, Nigeria. The region is in the derived savannah ecological zone of South-Western Nigeria and it falls within Latitude $7^{\circ} 13^{\prime} 37^{\prime \prime}$ $\mathrm{N}$ and Longitude $3^{\circ} 27^{\prime} 02^{\prime \prime} \mathrm{E}$ (Google Earth, 2021). The climatic condition is humid with a mean annual rainfall of $1037 \mathrm{~mm}$. The mean annual temperature and humidity are $34.7^{\circ} \mathrm{C}$ and $82 \%$, respectively.

\section{Collection and processing of test ingredient}

Fresh turmeric rhizomes were sourced from a reputable market within Abeokuta, Ogun State, Nigeria. The rhizomes were washed to remove debris and were air-dried until stable dry weight. Air-dried samples were milled to pass through a $1 \mathrm{~mm}$ sieve. Dried and milled samples were then stored at room temperature in air-tight glass container and kept away from sunlight for subsequent use. Aliquot of the air-dried samples were used for dry matter content determination and chemical analysis.

\section{Experimental substrate}

The experimental substrate used for in vitro studies consisted of Panicum maximum grass and a formulated concentrate supplement in the ratio 6:4 on dry matter basis. Air-dried and milled turmeric was incorporated in the substrate at different levels of $0,10,20,30 \mathrm{mg} / \mathrm{g}$ to make four different treatments. $P$. maximum was harvested from an existing pasture at $15 \mathrm{~cm}$ above ground level after six weeks of regrowth and chopped into sizes of about $2-4$ $\mathrm{cm}$. The concentrate feed mixture as formulated as complete feed using agroindustrial by-products. Known weights of the Panicum maximum also known as Guinea grass and concentrate samples $(n=3)$ were collected and oven-dried at $65^{\circ} \mathrm{C}$ to constant weight to obtain dry matter content. Oven dried and milled samples were analyzed for their chemical composition. The composition of $P$. maximum and the concentrate are presented in Table 1. 
An in-vitro evaluation of the potentials of turmeric as phytogenic feed additive

Table 1: Composition (\%) of experimental Panicum maximum and concentrate

\begin{tabular}{lll}
\hline Ingredient & Percentage composition & Panicum maximum \\
\hline Wheat offal & 48.00 & - \\
Maize & 17.00 & - \\
Brewers' dried grain & 32.00 & - \\
Bonemeal & 2.00 & - \\
Salt & 1.00 & - \\
Total & $\mathbf{1 0 0}$ & - \\
Nutrient composition & & \\
Dry matter & & 31.43 \\
Crude protein & 91.64 & 10.68 \\
Ether extract & 18.13 & 6.18 \\
Organic matter & 6.86 & 89.80 \\
Neutral detergent fibre & 93.88 & 68.38 \\
Acid detergent fibre & 53.95 & 30.63 \\
Acid detergent lignin & 22.51 & 18.11 \\
GE (MJ/kg DM) & 10.68 & 17.75 \\
ME (MJ/kg DM) & 19.05 & 12.24 \\
\hline Dry mattr & 12.55 &
\end{tabular}

${ }^{1}$ Dry matter on as-received basis

\section{Measurement of in vitro gas production}

The in vitro gas procedure of Menke and Steingass (1988) was followed, with slight modification. About $2 \mathrm{~L}$ of rumen fluid required for incubation was collected in the morning before feeding from three West African dwarf goats using suction method. The goats were previously fed on $60 \%$ grass and $40 \%$ concentrate diet. The concentrate contained $40 \%$ corn, $10 \%$ wheat offal, $10 \%$ palm kernel cake, $20 \%$ groundnut cake, $5 \%$ soya bean meal, $10 \%$ dried brewers' grain, $1 \%$ common salt, 3.75 oyster shell and $0.25 \%$ fish meal. The rumen fluid collected was strained through four-layered cheese cloth into warm $\left(39^{\circ} \mathrm{C}\right)$ thermo-flask and taken to the laboratory. A medium containing micro and macro nutrients, buffer solution, reduction solution and resazurin were mixed with the rumen liquor at ratio 2: $1(\mathrm{v} / \mathrm{v})$ to obtain the inoculum used for digestion. The mixture was handled under continuous anaerobic condition. There were four treatment samples according to the different levels of turmeric inclusion. Approximately $200 \mathrm{mg}$ of the samples ( $\mathrm{n}=10$ per treatment) were weighed into dacron bags $(2 \mathrm{~mm}$ by $5 \mathrm{~mm}$ size) of known weights and inserted into $100 \mathrm{ml}$ glass syringes. The syringes were then filled with $30 \mathrm{~mL}$ inoculum. The piston of the syringes was pushed upwards to eliminate air completely in the inoculum. A silicon tube inserted at the tip of the syringe was tightened by a metal clip to prevent escape of gas during the incubation process. Incubation was carried out at $39^{\circ} \mathrm{C}$ and the volume of gas produced was measured at three hours (h) interval from 0 to 48 -h. Three blanks of syringes containing $30 \mathrm{~mL}$ of medium only was included in the run to correct for gas production not arising from substrate degradation. The volume of gas produced from the blanks was deducted from the volume of gas produced per sample.

\section{Determination of methane production}

At the end of 48-h incubation, the volume of methane gas produced from the fermentation of substrates was determined by dispensing $4 \mathrm{~mL}$ of $10 \mathrm{~N}$ sodium hydroxide into each of the syringes ( $\mathrm{n}=5$ for each treatment group) through the silicon tube. Sodium hydroxide was added to absorb carbon-dioxide produced during the process of fermentation and the remaining 


\section{Aderinboye and Olanipekun}

volume of gas was recorded as methane according to the method of Fievez et al. (2005).

\section{Determination of ammonia nitrogen and total volatile fatty acids}

After 48- $\mathrm{h}$ incubation, $10 \mathrm{~mL}$ sample $(\mathrm{n}=$ 20; 4 treatment $\times 5$ replicates) and $5 \mathrm{~mL}$ sample $(n=20 ; 4$ treatment $\times 5$ replicates $)$ of digestion liquor was collected for ammonia nitrogen and total volatile fatty acids, respectively. The concentration of rumen ammonia nitrogen in the digestion liquor was determined using the micro-Kjeldahl method according to A.O.A.C (2000). Total volatile fatty acids were determined following the procedure of Barnett and Reid (1957).

\section{Microbial analysis}

The conventional roll-tube technique (Hungate, 1969) was used for culturing and isolation of bacteria, protozoa and fungi from rumen fluid. Each organism was identified according to Cowan and Steel (1993) method of microbial identification. Microbial count was done according to Galyean (1989) method of total direct count.

\section{Chemical analyses}

Dried samples of $P$. maximum, concentrate and turmeric powder were analyzed for proximate composition (AOAC, 2000) and fibre fractions (Van Soest et al., 1991). Metabolizable energy content was estimated according to De Boever et al. (1997). Gross energy estimated according to Weiss and Tebbe (2019) and value obtained in Mcal $/ \mathrm{kg}$ was multiplied by 4.184 for conversion to $\mathrm{MJ} / \mathrm{kg}$. Curcumin content in turmeric was determined following the procedure of Singh et al. (2012). Tannin (Makkar, 2003), total phenol (Do et al., 2014), flavonoids (Nasseri et al., 2019). Oxalate (Mishra et al., 2017) and saponin (Mir et al., 2016) contents were also determined in turmeric.

\section{Experimental design and statistical analysis}

The experiment was arranged as a completely randomized design. Data collected under this study were analyzed using the one-way analysis of variance (SAS, 2002). The experimental model is as shown below:

$Y_{i j}=\mu+T_{i}++\Sigma_{i j}$

Where: $Y_{i j k}$ is the observation, $\mu$ is the population mean, $T_{i}$ is the effect of turmeric levels in substrate $(i=1-4)$, and $\sum_{i j}$ is the residual error. Significant differences among means were compared using Duncan multiple range test (SAS, 2002).

\section{Results and discussion}

The phytochemical composition of turmeric as determined in this study (Table 2) revealed the presence of curcumin, total phenol, tannin, flavonoid, oxalate and saponin. Of the phytochemicals determined, curcumin had the highest percentage composition of $3.52 \%$. This value was comparable to the value of $3.14 \%$ reported by Tayyem et al. (2006) and within the range of 2.85 and $4.32 \%$ reported by Pawar et al. (2014) for curcumin content in turmeric samples. Curcumin has been reported as the active ingredient in turmeric known to be responsible for various biological activities (Tayyem et al., 2006; Kebede et al., 2021).

The gas production from in vitro degradation of substrate containing varying levels of turmeric powder is shown in Table 3. At the end of $27-\mathrm{h}$ incubation period, turmeric reduced $(p<0.05)$ gas volumes at each level of inclusion relative to the control. However, at the end of 48-h, gas volumes were significantly $(\mathrm{p}<0.05)$ reduced only at levels above $5 \mathrm{mg} / \mathrm{g}$ of inclusion. Gas production in the rumen is a direct result of microbial fermentation of carbohydrate (Yang, 2017), therefore, the observed reduction effect of turmeric on gas production suggests its potential to inhibit carbohydrate degradation in the rumen. The loss of the reduction effect of turmeric at 5 
$\mathrm{mg} / \mathrm{g}$ after $27-\mathrm{h}$ of incubation suggests that at lower levels of inclusion, microbes can adapt to turmeric inclusion in substrate during fermentation, over a period. The fermentation end-products from the degradation of substrates incubated with varying levels of turmeric is shown in Table 4. Turmeric altered $(\mathrm{p}<0.05)$ fermentation at levels above $5 \mathrm{mg} / \mathrm{g}$ of substrate. Turmeric decreased $(\mathrm{p}<0.05)$ the concentration of methane, carbon-dioxide, ammonia nitrogen and total volatile fatty acids at all levels of inclusion. The observed reduction in total volatile fatty acids might be reflection of reduced acetic acid and butyrate since gas production is assumed to occur when substrate carbohydrate is fermented to acetate and butyrate (Yang, 2017). The reduction in ammonia was attributed to inhibition of substrate protein degradation by microorganisms. This reduction effect of turmeric on ammonia could be beneficial in optimizing the utilization of dietary proteins in the rumen.

Table 2: Phytochemical composition of experimental turmeric

\begin{tabular}{ll}
\hline Constituents & Composition $^{\mathbf{1}}$ \\
\hline Curcumin $(\%)$ & 3.52 \\
Total phenols $(\mathrm{mg} / \mathrm{kg})$ & 3107.83 \\
Tannin $(\mathrm{mg} / \mathrm{kg})$ & 1455.75 \\
Flavonoid $(\mathrm{mg} / \mathrm{kg})$ & 465.26 \\
Oxalate $(\mathrm{mg} / \mathrm{kg})$ & 370.5 \\
Saponin $(\%)$ & 0.82 \\
\hline
\end{tabular}

${ }^{1}$ To convert from $\mathrm{mg} / \mathrm{kg}$ to $\%$, divide value by 10,000

Table 3: Total gas production ( $\mathrm{m} / 200 \mathrm{mgDM}$ ) from degradation of substrate in response to turmeric inclusion

\begin{tabular}{llllll}
\hline & \multicolumn{4}{c}{ Turmeric inclusion levels in substrate degraded, $\mathbf{~ g / g}$} & \\
\cline { 2 - 5 } Incubation hour & $\mathbf{0}$ & $\mathbf{5}$ & $\mathbf{1 0}$ & $\mathbf{1 5}$ & SEM \pm \\
\hline 3 & $0.47^{\mathrm{a}}$ & $0.40^{\mathrm{ab}}$ & $0.00^{\mathrm{c}}$ & $0.13^{\mathrm{bc}}$ & 0.056 \\
6 & $2.47^{\mathrm{a}}$ & $2.00^{\mathrm{b}}$ & $1.40^{\mathrm{c}}$ & $0.60^{\mathrm{bc}}$ & 0.090 \\
9 & $3.00^{\mathrm{a}}$ & $2.87^{\mathrm{a}}$ & $2.20^{\mathrm{b}}$ & $2.00^{\mathrm{b}}$ & 0.099 \\
12 & $5.13^{\mathrm{a}}$ & $4.53^{\mathrm{a}}$ & $3.87^{\mathrm{b}}$ & $3.73^{\mathrm{b}}$ & 0.127 \\
15 & $8.40^{\mathrm{a}}$ & $7.53^{\mathrm{b}}$ & $6.47^{\mathrm{c}}$ & $6.27^{\mathrm{c}}$ & 0.173 \\
18 & $11.20^{\mathrm{a}}$ & $9.87^{\mathrm{b}}$ & $8.40^{\mathrm{c}}$ & $8.00^{\mathrm{c}}$ & 0.265 \\
21 & $17.67^{\mathrm{a}}$ & $12.20^{\mathrm{b}}$ & $10.60^{\mathrm{c}}$ & $9.80^{\mathrm{c}}$ & 0.294 \\
24 & $20.07^{\mathrm{a}}$ & $16.33^{\mathrm{b}}$ & $14.80^{\mathrm{bc}}$ & $12.80^{\mathrm{c}}$ & 0.391 \\
27 & $22.25^{\mathrm{a}}$ & $18.50^{\mathrm{b}}$ & $17.75^{\mathrm{bc}}$ & $16.00^{\mathrm{c}}$ & 0.511 \\
30 & $25.13^{\mathrm{a}}$ & $22.43^{\mathrm{ab}}$ & $21.80^{\mathrm{b}}$ & $18.75^{\mathrm{c}}$ & 0.535 \\
33 & $28.88^{\mathrm{a}}$ & $26.38^{\mathrm{ab}}$ & $25.13^{\mathrm{b}}$ & $20.88^{\mathrm{c}}$ & 0.550 \\
36 & $30.13^{\mathrm{a}}$ & $28.75^{\mathrm{ab}}$ & $28.50^{\mathrm{b}}$ & $24.00^{\mathrm{c}}$ & 0.643 \\
39 & $34.38^{\mathrm{a}}$ & $31.88^{\mathrm{ab}}$ & $30.63^{\mathrm{b}}$ & $25.38^{\mathrm{c}}$ & 0.629 \\
42 & $36.00^{\mathrm{a}}$ & $34.13^{\mathrm{ab}}$ & $32.00^{\mathrm{b}}$ & $26.88^{\mathrm{c}}$ & 0.557 \\
45 & $36.50^{\mathrm{a}}$ & $36.25^{\mathrm{ab}}$ & $34.80^{\mathrm{b}}$ & $30.88^{\mathrm{c}}$ & 0.653 \\
48 & $38.78^{\mathrm{a}}$ & $36.88^{\mathrm{ab}}$ & $35.38^{\mathrm{b}}$ & $32.71^{\mathrm{c}}$ & 0.742 \\
\hline a,b,c Means along the same row with different superscript are significantly different $(\mathrm{p}<0.05)$, SEM: & & &
\end{tabular}




\section{Aderinboye and Olanipekun}

According to Bach et al. (2005), dietary rumen degradable proteins results in ammonia production and if more than what rumen microbes can utilize, leads to the ammonia absorption of across the rumen wall, conversion to urea in the liver and excretion in the urine, which is a wasteful process. Manipulation of rumen protein degradation is considered the most effective strategy for reducing nitrogen $\mathrm{N}$ losses (Bach et al., 2005; Casalmiglia et al., 2010). The potentials of turmeric to reduce ammonia in the rumen was evident in this study and this reduction did not alter microbial biomass up to $10 \mathrm{mg} / \mathrm{g}$ of inclusion in the substrate. However, levels up to $15 \mathrm{mg} / \mathrm{g}$ consequently reduced microbial biomass. The reduced ammonia production with concomitant decrease in microbial biomass at $15 \mathrm{mg} / \mathrm{g}$ of turmeric inclusion implied that the amount of ammonia released was insufficient for efficient microbial protein synthesis in the rumen. Microbial protein synthesis is dependent on degradable nitrogen or proteins to supply ammonia for microbial utilization (Andrade-Montemayor et al., 2009). Although, fungi population was reduced at $15 \mathrm{mg} / \mathrm{g}$ of turmeric inclusion, the role of fungi in substrate degradation is not clearly understood. It is however, associated with the degradation of lignified plant tissues which are not degraded by other rumen microbes (Krause et al., 2003). The reduced effect of turmeric on microbial population was linked with the phytochemicals in turmeric which have been associated antimicrobial activities. Studies of Tyagi et al. (2015) reported strong antibacterial activity of curcumin against gram-positive and gram-negative bacteria. The antimicrobial effect of tannin, flavonoids, saponin and oxalate are well documented in literature (Anantasook et al., 2014; Kim et al., 2015; Wang et al., 2009; Benbati et al., 2013). Hence, the observed fermentation and microbial population reductions were assumed to be directly related to the effect of curcumin and other plant secondary metabolites present in turmeric. Plant secondary metabolites have been reported to possess diverse antimicrobial mechanisms which include the disruption of cell membrane, enzyme inhibition, substrate deprivation, and the prevention of bacterial colonization (Reddy et al., 2020).

Table 4: Rumen fermentation end -products ( $\mathrm{mL} / 200 \mathrm{mgDM})$ from degradation of substrate in response to turmeric inclusion

\begin{tabular}{|c|c|c|c|c|c|}
\hline \multirow[b]{2}{*}{ Incubation hour } & \multicolumn{4}{|c|}{ Turmeric inclusion levels in substrate degraded, mg/g } & \multirow[b]{2}{*}{$\mathrm{SEM} \pm$} \\
\hline & $\mathbf{0}$ & 5 & 10 & 15 & \\
\hline Methane production, $\%$ & $32.27^{\mathrm{a}}$ & $30.05^{\mathrm{ab}}$ & $23.75^{\mathrm{bc}}$ & $20.20^{\mathrm{c}}$ & 1.74 \\
\hline Carbon-dioxide, $\%$ & $61.78^{\mathrm{a}}$ & $57.64^{\mathrm{ab}}$ & $53.98^{\mathrm{ab}}$ & $49.74^{\mathrm{b}}$ & 1.80 \\
\hline Ammonia nitrogen, $\mathrm{mg} \%$ & $30.94^{\mathrm{a}}$ & $29.18^{\mathrm{a}}$ & $22.74^{\mathrm{b}}$ & $21.66^{\mathrm{b}}$ & 1.29 \\
\hline $\begin{array}{l}\text { Total volatile fatty acids, } \\
\mathrm{mM} / 100 \mathrm{~mL}\end{array}$ & $20.61^{\mathrm{a}}$ & $18.50^{\mathrm{ab}}$ & $16.31^{\mathrm{b}}$ & $15.11^{\mathrm{b}}$ & 0.79 \\
\hline Substrate degraded, mg & $139.11^{\mathrm{a}}$ & $130.50^{\mathrm{ab}}$ & $123.18^{\mathrm{bc}}$ & $116.36^{\mathrm{c}}$ & 2.80 \\
\hline Bacteria, $\times 10^{6} \mathrm{CFU} / \mathrm{mL}$ & $4.2^{\mathrm{a}}$ & $3.9^{\mathrm{a}}$ & $3.0^{\mathrm{c}}$ & $2.6^{\mathrm{c}}$ & 0.20 \\
\hline Protozoa, $\times 10^{6} \mathrm{CFU} / \mathrm{mL}$ & $1.7^{\mathrm{a}}$ & $1.6^{\mathrm{a}}$ & $0.9^{\mathrm{b}}$ & $0.8^{\mathrm{b}}$ & 0.14 \\
\hline Fungi, $\times 10^{6} \mathrm{CFU} / \mathrm{mL}$ & $0.9^{\mathrm{a}}$ & $0.8^{\mathrm{ab}}$ & $0.7^{\mathrm{ab}}$ & $0.7^{\mathrm{b}}$ & 0.03 \\
\hline $\begin{array}{l}\text { Estimated microbial biomass, } \mathrm{mg} / \mathrm{g} \\
\text { DM }\end{array}$ & $47.44^{\mathrm{a}}$ & $45.44^{\mathrm{ab}}$ & $41.78^{\mathrm{ab}}$ & $37.89^{\mathrm{b}}$ & 1.60 \\
\hline
\end{tabular}


An in-vitro evaluation of the potentials of turmeric as phytogenic feed additive

\section{Conclusion}

This study revealed that turmeric inclusion above $5 \mathrm{mg} / \mathrm{g}$ DM in substate degraded in vitro altered rumen fermentation by reducing methane, carbon-dioxide, ammonia nitrogen and total volatile fatty acid production. Rumen bacteria and protozoa were also reduced at these levels of inclusion. Fungi population and microbial biomass were reduced. This effect of turmeric suggests it as a potential natural feed additive to modify rumen fermentation in ruminants. However, levels up to $15 \mathrm{mg} / \mathrm{g}$ DM inclusion can have a detrimental effect on microbial protein synthesis in the rumen.

\section{References}

Anantasook, N., Wanapat, M. and C h e r d t h o n g, A . 2014. Manipulation of rumen fermentation and methane production by supplementation with rain tree pod meal containing tannins and saponins in growing dairy steers. Journal of Animal Physiology and Animal Nutrition 98: 50-55

Andrade-Montemayor, H., Gasca, T. G. and Kawas, J. 2009. Ruminal fermentation modification of protein and carbohydrate by means of roasted and estimation of microbial protein synthesis. Revista Brasileira de Zootecnia 38: $277-291$.

AOAC. 2000. Official Methods of Analysis. The Association of Official Analytical Chemists, $17^{\text {th }}$ Edition Gaithersburg, MD, USA.

Bach, A., Calsamiglia, S. and Stern, M. D. 2005. Nitrogen metabolism in the rumen. Journal of Dairy Science 88: E9-E21.

Barnett, J. G. and Reid, R. L. 1957. Studies on the production of volatile fatty acids from grass by rumen liquor in an artificial rumen. The volatile fatty acid production grass. Journal of Agricultural Science 48: 315 - 321.

Benbati, M., Belenguer, A., Hervas, G., Toral, P. G. and Frutos, P. 2013. Effect of oxalic acid on rumen function and microbiota in sheep fed a low-quality diet In: Ben Salem H. and Lopez-Francos A. (eds.). Feeding and management strategies to improve livestock productivity, welfare and product quality under climate change. $\mathrm{Z}$ ar a g o $\mathrm{Z}$ a: C I H E A M / INRAT/OEP/IRESA/FAO. Options Mediterraneennes: Serie A. No. 107 p. 133 - 138

Calsamiglia, S., Ferret, A., Reynolds, C. K., Kristensen, N. B. and VaanVuuren, A. M. 2010. Strategies for optimizing nitrogen use by ruminants. Animal 4 (7): $1184-1196$

Castillo-Gonzalez, A. R., BurrolaBarraza, M. E., DominguezViveros, J. and ChavezMartinez, A. 2014. Rumen microorganisms and fermentation. Archivos de Medicina Veterinaria 40:349-361.

Chatzin asiou, L., Booker, A., MacLennan, E., Mackonochie, M. and Heinrich, M. 2019. Turmeric (Curcuma longa L.) products: What quality differences exist? Journal of Herbal Medicine 17-18: 100281

Chuntrakort, P., Otsuka, M., Hayashi, K., Takenaka, A., Udchachon, S. and Sommart, K. 2014. The effect of dietary coconut kernels, whole cottonseeds and sunflower seeds on the intake, digestibility and enteric methane emissions of Zebu beef cattle fed rice straw based diets. Livestock Science 161: 80 - 


\section{Aderinboye and Olanipekun}

89.

Compean, K. L. and Ynalvez, R. A. 2005. Antimicrobial Activity of Plant Secondary Metabolites: A Review. Research Journal of Medicinal Plants 8: 204 - 213.

Cowan, S. T and Steel, K. J. 1993.Enterobacteriacea, in G.I Barrow, R. K. A. Felthan, (Eds). Manual for the Identification of Medical Bacteria (3rd edition), Cambridge University press, United Kingdom, p. 213-218.

De Boever, J. L., Cottyn, B. G., De Brabandar, D. L., Vanacker, J. M. and Boucque, C. V. 1997. Prediction of the feeding value of maize silage by chemical parameters, in vitro digestibility and near infra-red spectroscopy (NIRS). Animal Feed Science and Technology 66:211 - 222.

Do, Q. D., Angkawijaya, A. E., TranNguyen, P. L., Huynh, L. H., Soetaredjo, F. E., Ismadji, S. and Ju-Hsu, Y. 2014. Effect of extraction solvent on total phenol content, total flavonoid content, and antioxidant activity of Limnophilaaromatica. Journal of Food and Drug Analysis 22: 296 302.

Eschenlaue, R. S. C. P., McKain, N., Walker, N, D., McEwan, N. R., Newbold, C. J. and Wallace, R. J. 2002. Ammonia production by ruminal microorganisms and enumeration, isolation, and characterization of bacteria capable of growth on peptides and amino acids from the sheep rumen Applied and Environmental Microbiology 68 (10): 4925 - 4931.

Fievez, V., Babayemi, O. J. and Demeyer, D. 2005. Estimation of direct and indirect gas production in syringes: a tool to estimate short chain fatty acid production requiring minimal laboratory facilities. Animal Feed Science and Technology (123-124): $197-210$.

Galyean, M. 1989. Laboratory Procedure in Animal Nutrition Research. Department of Animal and Life Science. New Mexico state University, U.S.A.


https://www.google.com/earth/. Viewed February 8, 2021.

Hassan, F., Arshad, M. A., Ebeid, H. M., Rehman, M. S., Khan, M. S., Shahid, S. and Yang, C. 2020. Phytogenic additives can modulate rumen microbiome to mediate fermentation kinetics and methanogenesis through exploiting diet-microbe interaction. Frontiers in Veterinary Science 7, Article $\begin{array}{lllllll}5 & 7 & 5 & 8 & 0 & 1 & \text { D O I : }\end{array}$ 10.3389 /fvets. 2020.575801 .

Hungate, R. E. 1969. A roll tube method for cultivation of strict anaerobes. In: Method in Microbiology. Norris, J. R. and Ribbons, D. W.(eds.). Academic Press. NY, 117 $-132$

Kebede, B. H., Forsidoa, S. F., Tola, Y. B., Astatkie, T. 2021. Free radical scavenging capacity, antibacterial activity and essential oil composition of turmeric (Curcuma domestica) varieties grown in Ethiopia. Heliyon 7 (2): e06239 https://doi.org/10.1016/j.heliyon.2 021.e06239.

Kim, E. T., Kim, C. H., Min, K. S., and Lee, S. S. 2012.Effects of plant extracts on microbial population, methane emission and ruminal fermentation characteristics in in vitro. Asian-Australasian Journal of Animal Sciences 25 (6): 806-811.

Krause, D. O., Denman, S. E., Mackie, R. I., Morrison, M., Rae, A. L., 
An in-vitro evaluation of the potentials of turmeric as phytogenic feed additive

Attwood, G. T., McSweeney, C.S. 2003. Opportunities to improve fiber degradation in the rumen: microbiology, ecology and genomics. FEMS Microbiology Reviews 27: 663 - 693.

Makkar, H. 2003. Effects and fate of tannins in ruminant animals, adaptation to tannins, and strategies to overcome detrimental effects of feeding tannin-rich feeds. Small Ruminant Research 49: 241 256.

Menke, K. H. and Steingass, H. 1988. Estimation of the energetic feed value obtained from chemical analysis and in vitro gas production using rumen fluid. Animal Research and Development 28: 7 55.

Mir, M. A., Parihar, K., Tabasum, U. and Kumari, E. 2016. Estimation of alkaloid, saponin and flavonoid, content in various extracts of Crocus sativa. Journal of Medicinal Plants Studies 4(5): 171-174.

Mishra, D. P., Mishra, N., Musale, H. B., Samal, P., Mishra, S. P. and Swain, D. P. 2017. Determination of seasonal and developmental variation in oxalate content of Anagallisarvensis plant by titration and spectrophotometric method.

The Pharma Innovation Journal 6(6): 105 - 111.

Nasseri, M. A., Behravesh, S., A l l a h res a ni, A. and Kazem nejadi, M. 2019 . Phytochemical and antioxidant studies of Cleome heratensis (Capparaceae) plant extracts. Bioresources and Bioprocessing 6: 5.

Patel, S. and Ambalam, P. 2018. Role of rumen protozoa: metabolic and fibrolytic. Advances in
Biotechnology and Microbiology $10(4): 79-84$

Patra, A., Park, T., Kim, M and Yu, Zhongtang. 2017. Rumen methanogens and mitigation of methane emission by antimethanogenic compounds and substances. Journal of Animal Science and Biotechnology 8, A r t i c 1 e 13 https://doi.org/10.1186/s40104017-0145-9

Pawar, H., Karde, M., Mundle, N., Jadhav, P. and Mehra, K. 2014. Phytochemical evaluation and curcumin content determination of turmeric rhizomes collected from Bhandara district of Maharashtra (India). Medicinal Chemistry 4(8): $588-591$

Pradeep, K., Ravi, R., Prakash, J. and Naidu, M. M. 2016. Influence of blanching and drying methods on the quality characteristics of fresh turmeric (Curcuma longa 1.) Rhizomes. International Journal of Applied and pure Science and Agriculture 2(3): 32 - 44.

Reddy, P. R. K., Elghandour, M. M. M. Y., Salem, A. Z. M., Yassawini, D., Reddy, P. P. R., Reddy, A. N. and Hyder, I. 2020. Plant secondary metabolites as feed additives in calves for antimicrobial stewardship. Animal Feed Science and Technology 264: 114469

SAS. 2002. Statistical analysis system version 9.1. SAS Institute Inc, Cary.

Subepang, S., Suzuki, T., Phonbumrung, T. and Sommart, Kritapon. 2019. Enteric methane emissions, energy partitioning, and energetic efficiency of zebu beef cattle fed total mixed ration silage. AsianAustralasian Journal of Animal Science 32: 548 - 555 
Tadesse, G. 2014. Rumen manipulation for enhanced feed utilization and improved productivity performance of ruminants: A review. Momona Ethiopian Journal of Science 6 (2): 3 - 17.

Tayyem, R. F., Heath, D. D., Al-Delaimy, W. K. and Rock, C. L. 2006. Curcumin content of turmeric and curry powder. Nutrition and Cancer 55 (2): 126 131.

Thangavel, K. and Dhivya, K.2019. Determination of curcumin, starch and moisture content in turmeric by Fourier transform near infrared spectroscopy (FT-NIR). Engineering in Agriculture, Environment and Food 12 (2): 264 -269 .

Tyagi, P., Singh, M., Kumari, H., Kumari, A. and Mukhopadhyay, K. 2015. Bactericidal activity of curcumin is associated with damaging of bacterial membrane. $P L O S \quad O N E \quad 10$ ( 3 ): e0121313.doi:10.1371/journal.po ne. 0121313

Ulfina, G., Lemma, F., Tadesse, T. and Bekuma, A. 2019. Rumen Manipulation: One of the Promising Strategies to Improve Livestock Productivity: Review. Journal of Dairy and Veterinary Sciences 9 (2): 555758.
Van Soest, P. J., Robertson, J. B. and Lewis, B. A. 1991. Methods for dietary fibre, neutral detergent fibre, and non-starch polysaccharides in relation to animal nutrition. Journal of Dairy Science 74: 3583 - 359.

Wanapat, M., Cherdthong, A., Phesatcha, K., Sungchhang, K. 2015. Dietary sources and their effects on animal production and environmental sustainability. Animal Nutrition 1:96-103.

Wang, C. J., Wang, S. P. and Zhou, H. 2009. Influences of flavomycin, ropadiar, and saponin on nutrient digestibility, rumen fermentation, and methane emission from sheep. Animal Feed Science and Technology 148 (2-4): 157-166.

Weiss, W. P. and Tebbe, A. W. 2019. Estimating digestible energy values of feeds and diets and integrating those values into net energy systems. Translational Animal Science 3 (3): 953-961

Yang, W. 2017. Factors Affecting Rumen Fermentation Using Batch Culture Technique In: Fermentation process. Jozala, A. F. (ed.). IntechOpen. DOI: $10.5772 / 64207$

Received: $17^{\text {th }}$ October, 2020 Accepted: $15^{\text {th }}$ February, 2021 